The Editor's recommendation of this issue's article to readers

\title{
INVESTIGATION OF THE CLINICAL AND MICROBIOLOGICAL EFFECTS OF DIFFERENT TOOTHPASTES: IN-VIVO STUDY
}

I am pleased to inform you that I have chosen this article by Koruyucu et al. ${ }^{l}$ as Editor's Choice for first issue of 2020.

Biofilm control is an important procedure for the removal of microbial dental biofilm to prevent tooth decay and periodontal disease and to prevent the accumulation of teeth and adjacent gingival surfaces. Toothpastes with antimicrobial effects have an important effect on the removal of both dental biofilm and gingivitis.

\begin{abstract}
This article shows that all tested toothpastes including fluoride-free, chlorite-containing and fluoride-containing, proved to be safe and significantly effective clinical and microbiological features
\end{abstract}

Happy readings and have a great year with increasing academic interest in 2020 !

Assoc. Prof. Burak Buldur

Co-Editor-in-Chief

\section{REFERENCE:}

1. Koruyucu M, Birant S, Topcuoglu S, Külekci G, Seymen F. Investigation of The Clinical and Microbiological Effects of Different Toothpastes: In-Vivo Study. Cumhuriyet Dent J 2020;23:1;22-31. 